\title{
Evalution of Bt cotton to different sowing windows and plant spacing under rainfed vertisol conditions
}

\author{
S. Subbulakshmi \\ Agricultural Research Station, Kovilpatti (T.N.) India \\ (Email: subbuagri@ rediffmail.com)
}

\begin{abstract}
The field experiments were conducted during 2010-11, 2011-12 and 2012-13 in Rabi season (Sep - Feb) at Agricultural Research station, Kovilpatti to study the response of Bt cotton to different dates of sowing under varying spacing. Experiments were laid out in split-plot design with three replications. The treatment combinations comprised of three dates of sowing, viz., $39^{\text {th }}$, $41^{\text {st }}$ and $43^{\text {rd }}$ standard weeks (pre-monsoon, monsoon and post-monsoon sowing, respectively) in main plot with four different spacing of $90 \times 60,90 \times 45,75 \times 60,75 \times 45$ in the sub plot. The results of the experiment revealed that, pre-monsoon sowing of cotton (NCS 145) registered increased growth and yield parameters viz., plant height, DMP, LAI, number of bolls/plant, boll weight, which reflected on increased yield of cotton kapas (1434, 2430 and $\left.347 \mathrm{~kg} \mathrm{ha}^{-1}\right)$ in 2011, 2012 and 2013, respectively. Similarly among the spacing tried, $75 \times 45 \mathrm{~cm}\left(\mathrm{~S}_{4}\right)$ registered increased plant height, dry matter production, LAI and number of symbodial branches which reflected on increased kapas yield which was followed by spacing of $90 \times 45 \mathrm{~cm}$. Interaction result shows that, $39^{\text {th }}$ standard week (pre-monsoon) sowing with narrow spacing of $75 \times 45 \mathrm{~cm}$ registered increased kapas yield under rain-fed condition.
\end{abstract}

Key Words : Cotton, Growth, Spacing, Sowing window, Yield

View Point Article : Subbulakshmi, S. (2019). Evalution of Bt cotton to different sowing windows and plant spacing under rainfed vertisol conditions. Internat. J. agric. Sci.,15(2):271-274, DOI:10.15740/HAS/IJAS/15.2/271-274. Copyright@2019: Hind Agri-Horticultural Society.

Article History : Received : 15.01.2019; Revised : 09.05.2019; Accepted : 16.05.2019 